\title{
Pengembangan Instrumen Penilaian Sikap Tanggung Jawab Pembelajaran Tematik Terpadu Kelas V SD
}

\section{Aulia Ika Wulandari1*, Elvira Hoesein Radia²}

${ }^{12}$ Program Studi Pendidikan Guru Sekolah Dasar, Universitas Kristen Satya Wacana, Salatiga, Indonesia

\begin{tabular}{l} 
A R T I C L E I N F O \\
\hline Article history: \\
Received 1 Januari 2021 \\
Received in revised form \\
30 Januari 2021 \\
Accepted 1 Maret 2021 \\
Available online 8 April \\
2021 \\
\hline
\end{tabular}

Kata Kunci: pengembangan, penilaian sikap, tematik terpadu

Keywords: development, attitude assessment, thematic integrated

\begin{abstract}
A B S T R A K
Pelaksanaan penilaian ranah sikap belum maksimal karena guru hanya mengamati sikap siswa tanpa mengacu pada instrumen yang baku untuk mengukur sikap sosial siswa khususnya sikap tanggung jawab. Penelitian ini dilaksanakan dengan tujuan menghasilkan produk instrumen penilaian sikap tanggung jawab pembelajaran tematik terpadu kelas 5 tema 6 . Jenis penelitian ini adalah penelitian pengembangan (R\&D). Subjek penelitian adalah siswa kelas 5 Sekolah Dasar. Sampel ditentukan menggunakan teknik random sampling dengan sampel sebanyak 30 siswa. Teknik pengumpulan data yang digunakan adalah instrumen berupa angket menggunakan skala Likert. Analisis data penelitian bersifat deskriptif kategori. Berdasarkan uji ahli evaluasi sikap diperoleh skor $76 \%$ dikategorikan validitas tinggi dan layak diujicobakan. Berdasarkan penilaian ahli bahasa diperoleh skor $80 \%$ dikategorikan tingkat validitas tinggi dan layak diujicobakan. Hasil uji coba terbatas menunjukkan bahwa instrumen sikap sosial dari 30 (tiga puluh) item pernyataan diperoleh data; tingkat validitas instrumen menunjukkan rhitung terendah adalah 0.385 , memiliki nilai Pearson Correlation XTot $\geq 0,361$ sehingga 30 butir pernyataan dikategorikan valid; reliabilitas instrumen penilaian sikap tanggung jawab menunjukkan $\alpha=0.944$ dengan kriteria
\end{abstract} sangat reliabel atau sangat andal. Berdasarkan uji coba terbatas tersebut maka instrumen penilaian sikap sosial tanggung jawab valid dan reliabel sehingga layak untuk digunakan.

\begin{abstract}
A B S T R A C T
The implementation of the attitude assessment has not been optimal because the teacher only observes students 'attitudes without referring to standard instruments to measure students' social attitudes, especially the attitude of responsibility. This research was carried out to produce an integrated thematic learning responsibility attitude assessment instrument for class 5 theme 6. This type of research is development research $(R \& D)$. The research subjects were grade 5 elementary school students. The sample was determined using a random sampling technique with a sample of 30 students. The data collection technique used was a questionnaire instrument using a Likert scale. The research data analysis was categorical descriptive. Based on the expert test of attitude evaluation, it was found that a score of $76 \%$ was categorized as high validity and was worthy of being tested. Based on the linguist's assessment, the score of $80 \%$ was categorized as a high level of validity and was worth trying out. The results of the limited trial showed that the social attitude instrument of 30 (thirty) statement items obtained data; the validity level of the instrument shows that the lowest rcount is 0.385 , has a Pearson Correlation XTot value $\geq 0.361$ so that 30 statements are categorized as valid; the reliability of the instrument of responsibility attitude assessment shows $\alpha=$ 0.944 with the criteria very reliable or very reliable. Based on this limited trial, the assessment instrument for social responsibility attitudes is valid and reliable so it is feasible to use.
\end{abstract}

\section{Pendahuluan}

Perbaikan kurikulum pembelajaran terus dilakukan oleh pemerintah untuk menyempurkan kurikulum lama dan mengikuti perkembangan jaman. Kurikulum 2013 ditetapkan untuk menggantikan kurikulum KTSP (Kurikulum Tingkat Satuan Pendidikan), dengan harapan bahwa 
pembelajaran bukan hanya berfokus pada pengetahuan tetapi juga pada ranah sikap dan keterampilannya (Dessiane \& Kristin, 2021; Nugraha, 2017; Putra \& Amalia, 2020). Kurikulum Sekolah Dasar 2013 didasarkan oleh PP Nomor 17 Tahun 2010 tentang Pengelolaan dan Penyelenggaraan Pendidikan. Implementasi kurikulum 2013 dengan pembelajaran tematik ini diharapkan siswa dapat memperoleh pengetahuan secara utuh dengan secara bersamaan mengembangkan sikap spiritual, dan rasa ingin tahu, kreativitas, kerja sama dengan kemampuan intelektual dan psikomotoriknya (Mulyadin, 2016; Purwanti, 2019). Disamping tersedianya kurikulum yang handal, salah satu aspek terpenting dalam upaya menjamin kualitas layanan pendidikan adalah menyediakan sistem penilaian yang komprehensif sesuai dengan standar nasional pendidikan yang telah ditetapkan. Penilaian hasil belajar dalam Kurikulum 2013 menggunakan penilaian autentik yang mengukur 3 ranah yakni aspek sikap, pengetahuan, dan keterampilan. Penilaian dalam pembelajaran kurikulum 2013 harus dilakukan secara menyeluruh, agar dapat menggambarkan kondisi peserta didik secara menyeluruh (Astuti \& Darsinah, 2018; Kurniaman \& Noviana, 2017).

Sikap yang dinilai ini merupakan sikap hasil belajar. Perlu dilakukan penilaian yang menggunakan instrumen yang benar-benar mengukur kompetensi peserta didik yang dihasilkan melalui proses pembelajaran (Adjii, 2019; Baidhowi, 2018). Mengukur sikap sosial terutama sikap tanggung jawab peserta didik, dapat dilakukan melalui observasi, penilaian diri, daftar cek, penilaian antar teman, atau skala penilaian yang disertai rubrik. Salah satu bentuk instrumen adalah instrumen skala penilaian. Instrumen penilaian yang berupa skala penilaian yang sering digunakan adalah skala Likert. Skala Likert adalah salah satu skala yang dikembangkan untuk mengukur sikap seseorang, pendapat seseorang atau kelompok yang sama (Mawardi, 2014; Widoyoko, 2014). Namun, dalam pelaksanaan penilaian sikap siswa, ditemukan informasi bahwa banyak guru yang merasa kesulitan dan dirasa cukup rumit dalam melaksanakan penilaian sikap sosial. Sulitnya untuk menilai sikap siswa secara individu dikarenakan jumlah siswa yang cukup banyak serta banyaknya sekolah yang belum mampu mengembangkan pembelajaran yang dapat mengembangkan kompetensi sikap sosial siswa, sehingga penilaian sikap yang dilaksanakan belum maksimal (Purwanti, 2019; Tursinawati, 2017).

Permasalahan ini juga terjadi pada salah satu sekolah dasar. Berdasarkan hasil observasi dan wawancara yang dilakukan di SD Negeri Kaligentong 2 Boyolali, diperoleh informasi bahwa guru belum melakukan penilaian sikap secara rinci dan menyeluruh. Guru juga jarang menggunakan instrumen yang sesuai dengan panduan penilaian sekolah dasar kurikulum 2013. Penilaian yang dilakukan guru selalu berpusat pada penilaian pengetahuan saja. Permasalahannya adalah belum ada pengembangan instrumen penilaian sikap yang sudah teruji kevalidannya dan reliabilitasnya. Hal tersebut disebabkan karena guru belum pernah mengembangkan dan kurangnya pemahaman dalam mengembangkan instrumen penilaian pembelajaran tematik ranah sikap sosial terkhusus sikap tanggung jawab. Instrumen yang digunakan guru belum bisa dikatakan layak digunakan karena guru menggunakan instrumen yang belum pernah diujikan sebelumnya. Instrumen yang baik haruslah instrumen yang dapat mengukur apa yang ingin diukur dan alat ukur yang memiliki hasil yang tepat, atau disebut valid dan reliabel (Sugiyono, 2015; Widoyoko, 2014).

Sikap sosial dan sikap spiritual masing-masing individu siswa tentunya telah terbentuk dari lingkungannya, salah satunya adalah lingkungan sekolah dan lingkungan bermainnya yang sangat menentukan bagaimana cara siswa bersikap terhadap lingkungan (Oviana, 2015; Utami, Purnomo, \& Salam, 2019). Guru dan perlu melakukan kajian terhadap sikap dan penilaian terhadap sikap siswa sehingga dapat dilakukan tindak lanjut dengan tepat (Sanjiwana, P.P.C.M Pudjawan \& Margunayasa, 2015; Wildan, 2017). Berdasarkan dengan kondisi belum adanya instrumen penilaian sikap yang teruji dan adanya kesulitan guru dalam menilai kompetensi inti sikap sosial, maka peneliti merasakan perlunya dilakukan perancangan dan pengembangan instrumen penilaian kompetensi inti sikap sosial secara khusus. Penilaian ranah sikap sosial terdiri dari penilaian sikap jujur, sikap disiplin, sikap percaya diri, sikap santun, sikap peduli, sikap kerja keras, sikap mandiri, sikap tanggung jawab (Darmansyah, 2014; Kuntoro \& Wardani, 2020). Penanaman sikap siswa serta pembiasaan perilaku baik dan pendidikan karakter dijenjang sekolah dasar sudah seharusnya sangat diperhatikan oleh guru (Dessiane \& Kristin, 2021; Widodo, Hariyono, \& Hanurawan, 2016).

Penelitian yang dilakukan oleh Prasanti (2017) menyatakan bahwa guru seringkali mengabaikan penilaian sikap. Minimnya keinginan guru untuk meningkatkan kemampuan dalam melakukan penilaian autentik sikap sosial. Guru menginginkan instrumen penilaian sikap sosial yang sederhana dan mudah dalam penerapannya. Guru kurang mampu melakukan penilaian sikap sosial 
yang disebabkan beberapa faktor, diantaranya adalah kurangnya pemahaman guru terhadap teknik penilaian sosial, dengan ditandai banyaknya guru yang menginginkan penilaian sikap sosial yang valid dan reliabel serta mudah digunakan, pemahaman yang sering diterima guru adalah penilaian sikap sosial hanya menggunakan teknik observasi. Umumnya guru sesekali mengembangkan instrumen penilaian sesaat sebelum penilaian dilaksanakan (Sari, 2017; Wildan, 2017). Penelitian yang dilakukan oleh Candra, Sulistya, \& Prasetyo (2018) menyatakan bahwa guru kesulitan dalam melakukan penilaian sikap, terutama sikap sosial hal tersebut disebabkan karena penilaian guru terhadap siswa tidak menggunakan instrumen penilaian sikap yang sesuai dengan tema dan pembelajaran yang sedang berlangsung.

Berdasarkan permasalahan tersebut penelitian ini bertujuan untuk menghasilkan alat ukur sikap sosial siswa, mengetahui cara mengembangkan instrumen penilaian sikap sosial dengan menggunakan skala Likert pembelajaran tematik kelas 5, serta untuk menguji kelayakan alat ukur yang valid dan reliabel. Penilaian ini menghasilkan produk berupa instrumen penilaian sikap dengan teknik self assessment dengan menggunakan skala Likert. Selain menghasilkan instrumen, juga menghasilkan pedoman penilaian mulai dari perencanaan, proses penilaian, dan pengelolaan hasil penilaian yang berupa predikat dan deskripsi hasil yang dicapai siswa. Penelitian ini diharapkan dapat membantu guru untuk dijadikan bahan pertimbangan dalam mengembangkan instrumen penilaian sikap sosial tanggung jawab dalam pembelajaran tematik kelas V tema 6 Panas dan Perpindahannya subtema 3 Pengaruh Kalor Terhadap Kehidupan pembelajaran 4 khususnya muatan pelajaran PPKn, Bahasa Indonesia, dan IPS serta tema-tema berikutnya. Dapat juga digunakan sebagai bahan referensi bagi guru dalam mengembangkan instrumen penilaian sikap sosial yang disesuaikan dengan KI dan KD yang digunakan.

\section{Metode}

Jenis penelitian ini adalah penelitian pengembangan atau Research and Development (R\&D). Penelitian ini mengembangkan suatu produk yang sudah ada atau mengembangkan satu produk baru yang dapat dipertanggungjawabkan. Prosedur penelitian mengacu pada langkah-langkah menurut Sukmadinata (2013) (modifikasi dari Borg and Gall). Langkah penelitian ini secara garis besar terdiri dari 3 tahap yaitu: 1) Studi Pendahuluan, 2) Pengembangan, dan 3) Pengujian. Tempat penelitian ini di SD Negeri 2 Kaligentong Boyolali pada semester 2 tahun pelajaran 2020/2021 yaitu pada bulan Februari. Subjek penelitiannya adalah siswa kelas V yang berjumlah 30 siswa.

Metode pengumpulan data yang digunakan adalah teknik observasi, wawancara, kuesioner, dan angket. Wawancara dilakukan untuk memperoleh data secara langsung dari pihak guru kelas 5 . Data kuantitatif diperoleh dari uji ahli dan uji coba lapangan terbatas. Kuesioner untuk menguji kevalidan produk sebelum diujicobakan, dan dinilai oleh ahli evaluasi sikap dan ahli bahasa. Angket adalah instrumen pengukuran sikap tanggung jawab untuk mengumpulkan data primer. Pengukuran sikap tanggung jawab siswa dilaksanakan dengan menggunakan alat ukur berupa angket pengukuran sikap tanggung jawab dengan menggunakan skala Likert.

Data hasil uji ahli (expert judgement) dianalisis menggunakan teknik deskriptif persentase dan kategori untuk menggambarkan kelayakan uji coba produk. Skor hasil pengukuran menggunakan angket tertutup. Angka persentase kemudian dikelompokkan kedalam kategori tabel sebagai berikut.

Tabel 1. Kategori Uji Validasi Ahli

\begin{tabular}{cc}
\hline Interval & Kategori \\
\hline $81-100 \%$ & Sangat tinggi \\
$61-80 \%$ & Tinggi \\
$41-60 \%$ & Cukup \\
$21-40 \%$ & Rendah \\
$0-20 \%$ & Sangat Rendah \\
\hline
\end{tabular}

Data hasil pengujian akan diolah dengan teknik pengolahan data deskriptif kategori, persentase, dan uji validitas serta reliabilitas. Validitas dan reliabilitas instrumen diolah dan dilihat menggunakan program IBM SPSS 24 for windows. 


\section{Hasil dan Pembahasan}

Studi pendahuluan dilakukan dengan studi literatur dan studi lapangan, studi literatur mengkaji kurikulum 2013 khususnya tingkat Sekolah Dasar dan untuk mengetahui konsep dan teori yang digunakan untuk membuat instrumen penilaian sikap sosial yang akan dikembangkan dalam penelitian ini. Hasil yang ditemukan dan dijadikan dasar yaitu pembelajaran tematik yang KI dan Kdnya dapat dikembangkan, yaitu Tema 6 "Panas dan Perpindahannya" subtema 3 "Pengaruh Kalor terhadap Kehidupan" pembelajaran 4 dengan muatan pelajaran PPKn, Bahasa Indonesia, dan IPS. Kajian dalam mengembangkan instrumen penilaian sikap sosial juga ditemukan tahapan-tahapan dalam mengembangkan instrumen sikap menggunakan skala Likert.

Setelah studi literatur, dilakukan studi lapangan terhadap guru kelas V. Hasil wawancara dan observasi dengan guru kelas V SD Negeri 2 Kaligentong Boyolali, ditemukan bahwa belum tersedianya alat ukur ranah sikap tanggung jawab yang baku yakni teruji validitas dan reliabilitasnya. Penilaian pun tidak dilaksanakan secara menyeluruh karena instrumen yang ada biasanya hanya melalui observasi yang biasanya belum mengukur pengetahuan sikap siswa yang sebenarnya, serta kendala kemampuan guru dan kendala waktu bagi guru yang ingin mengembangkan instrumen penilaian yang baku.

Tahap pengembangan Instrumen Sikap Tanggung Jawab Kelas V Semester 2, dilakukan dengan pendekatan model pengembangan ADDIE (Analysis, Design, Development, Implementation, dan Evaluation). Tahap pertama, yaitu Analisis. Berdasarkan analisis kinerja yang dilaksanakan dengan wawancara dan observasi pada SD Negeri 2 Kaligentong, di kecamatan Ampel, kabupaten Boyolali. Hasil menunjukkan bahwa sangat jarang dan hanya dilaksanakan terkadang hanya satu kali di setiap semesternya dalam penilaian sikap tanggung jawab siswa kelas V. Analisis kebutuhan yang dijadikan dasar penelitian ini, dan peneliti memutuskan untuk mengembangkan instrumen penilaian sikap tanggung jawab kelas 5 Tema 6 "Panas dan Perpindahannya" subtema 3 "Pengaruh Kalor terhadap Kehidupan" pembelajaran 4. Tahap Kedua yaitu desain. Tema 6 "Panas dan Perpindahannya" subtema 3 "Pengaruh Kalor terhadap Kehidupan” pembelajaran 4 dipilih karena memiliki KD yang mengandung aspek kompetensi sikap tanggung jawab yang sesuai dengan ranah sikap pada instrumen yang akan dikembangkan oleh peneliti. Kompetensi inti ranah sikap adalah KI.2, untuk KI.2 kelas V adalah "Menunjukkan perilaku jujur, disiplin, tanggung jawab, santun, peduli, dan percaya diri dalam berinteraksi dengan keluarga, teman, guru, tetangga, dan negara". Selanjutnya dikaji silabus kelas V dan dipilih KD 2.2, kemudian ditentukan indikator, komponen indikator, aspek sikap, aspek yang diamati, yang disajikan dalam kisi-kisi instrumen. Kisi-kisi yang dikembangkan menjadi patokan dalam pembuatan butir pernyataan yang akan digunakan sebagai alat ukur sikap aspek kognisi, afeksi, dan konasi. Proses pengembangan produk, berfokus pada pengembangan indikator sikap tanggung jawab saja. Kisi-kisi yang telah disusun disajikan dalam tabel berikut ini.

Tabel 2. Kisi-Kisi Instrumen Sikap Tanggung Jawab

\begin{tabular}{|c|c|c|c|c|c|}
\hline $\begin{array}{l}\text { Kompetensi } \\
\text { Dasar }\end{array}$ & Indikator & $\begin{array}{l}\text { Komponen } \\
\text { Indikator }\end{array}$ & $\begin{array}{l}\text { Aspek } \\
\text { Sikap }\end{array}$ & Aspek yang diamati & $\begin{array}{l}\text { Jumlah } \\
\text { Item }\end{array}$ \\
\hline 2.2 & 2.2 .1 & Hakikat tanggung & Kognisi & Hakikat tanggung jawab & 2 \\
\hline Menunjukkan & Menunjukkan & jawab & & & \\
\hline $\begin{array}{l}\text { sikap } \\
\text { tanggung }\end{array}$ & $\begin{array}{l}\text { sikap } \\
\text { tanggung }\end{array}$ & Belajar & Konasi & $\begin{array}{l}\text { Selalu belajar karena tanggung } \\
\text { jawabnya sebagai siswa }\end{array}$ & 2 \\
\hline jawab dalam & jawab dalam & Melaksanakan & Kognisi & Hakikat melaksanakan tugas & 2 \\
\hline $\begin{array}{l}\text { memenuhi } \\
\text { kewajiban } \\
\text { dan hak }\end{array}$ & $\begin{array}{l}\text { kehidupan } \\
\text { sehari-hari. }\end{array}$ & tugas & Afeksi & $\begin{array}{l}\text { Setuju atau tidak setuju untuk } \\
\text { menyelesaikan tugas yang } \\
\text { dibagikan saat tugas kelompok }\end{array}$ & 2 \\
\hline $\begin{array}{l}\text { sebagai } \\
\text { warga }\end{array}$ & & & Konasi & $\begin{array}{l}\text { Seharusnya mengumpulkan } \\
\text { tugas tepat waktu }\end{array}$ & 2 \\
\hline $\begin{array}{l}\text { masyarakat } \\
\text { dalam } \\
\text { kehidupan }\end{array}$ & & $\begin{array}{l}\text { Taat pada } \\
\text { peraturan sekolah }\end{array}$ & Afeksi & $\begin{array}{l}\text { Suka atau tidak suka } \\
\text { melaksanakan piket sesuai } \\
\text { jadwal }\end{array}$ & 2 \\
\hline
\end{tabular}




\begin{tabular}{|c|c|c|c|c|c|}
\hline $\begin{array}{c}\text { Kompetensi } \\
\text { Dasar }\end{array}$ & Indikator & $\begin{array}{l}\text { Komponen } \\
\text { Indikator }\end{array}$ & $\begin{array}{l}\text { Aspek } \\
\text { Sikap }\end{array}$ & Aspek yang diamati & $\begin{array}{c}\text { Jumlah } \\
\text { Item }\end{array}$ \\
\hline \multirow[t]{9}{*}{ sehari-hari. } & & & Konasi & $\begin{array}{l}\text { Harus selalu memakai pakaian } \\
\text { yang sopan dan sesuai } \\
\text { peraturan }\end{array}$ & 2 \\
\hline & & $\begin{array}{l}\text { Patuh dan hormat } \\
\text { pada guru }\end{array}$ & Afeksi & $\begin{array}{l}\text { Merasa senang atau tidak } \\
\text { senang saat guru memberi } \\
\text { nasehat kepada saya. }\end{array}$ & 2 \\
\hline & & & Konasi & $\begin{array}{l}\text { Selalu mendengarkan nasihat } \\
\text { dari orang yang lebih tua. }\end{array}$ & 2 \\
\hline & & Mengakui & Kognisi & Hakikat mengakui kesalahan & 2 \\
\hline & & kesalahan & Afeksi & $\begin{array}{l}\text { Setuju atau tidak setuju untuk } \\
\text { menerima resiko dari tindakan } \\
\text { yang dilakukan }\end{array}$ & 2 \\
\hline & & & Konasi & $\begin{array}{l}\text { Saya seharusnya meminta } \\
\text { maaf atas kesalahan yang saya } \\
\text { perbuat. }\end{array}$ & 2 \\
\hline & & Disiplin & Afeksi & $\begin{array}{l}\text { Suka atau tidak suka untuk } \\
\text { mengembalikan barang yang } \\
\text { dipinjam }\end{array}$ & 2 \\
\hline & & & Konasi & $\begin{array}{l}\text { Selalu merawat buku pelajaran } \\
\text { yang dipinjamkan oleh } \\
\text { perpustakaan }\end{array}$ & 2 \\
\hline & & $\begin{array}{l}\text { Menjaga nama } \\
\text { baik sekolah }\end{array}$ & Afeksi & $\begin{array}{l}\text { Seharusnya berusaha secara } \\
\text { maksimal untuk meraih } \\
\text { prestasi yang baik }\end{array}$ & 2 \\
\hline
\end{tabular}

Tahap ketiga yaitu pengembangan. Pada tahap development, dikembangkan instrumen sikap tanggung jawab menjadi butir-butir pernyataan dengan skala Likert. 30 butir pernyataan yang terdiri dari pernyataan positif (favorable) dan negatif (unfavorable). Responden memberikan jawaban setiap item instrumen yang menggunakan skala Likert mempunyai gradasi dari sangat positif sampai sangat negatif, yang dapat berupa kata-kata antara lain: sangat setuju (SS), setuju (ST), ragu-ragu (R), tidak setuju (TS) dan sangat tidak setuju (STS). Pengolahan data responden angket akan dikuantifikasikan dengan skor jawaban sebagai berikut: skor pernyataan positif (favorable): sangat setuju = 5; setuju = 4; ragu-ragu $=3$; tidak setuju $=2$; sangat tidak setuju $=1$; skor pernyataan negatif (unfavorable): sangat setuju $=1$; setuju $=2$; ragu-ragu $=3$, tidak setuju $=4$; sangat tidak setuju $=5$. Produk yang telah dikembangkan diuji kelayakan kepada ahli bahasa dan ahli evaluasi adalah sebagai berikut.

Tabel 3. Persentase Hasil Telaah Tim Ahli

\begin{tabular}{clcc}
\hline No. & Bidang & Skor & Kriteria \\
\hline 1. & Ahli Evaluasi & $76 \%$ & Tinggi \\
2. & Ahli Bahasa & $80 \%$ & Tinggi \\
\hline
\end{tabular}

Produk awal diserahkan ke 2 dosen ahli. Tahap uji validasi terhadap ahli evaluasi memperoleh skor $76 \%$ termasuk dalam kategori tinggi untuk tingkat validitasnya. Aspek yang dinilai meliputi aspek substansi, konstruksi, dan bahasa. Ahli bahasa memperoleh skor $80 \%$ termasuk dalam kategori tinggi. Aspek yang dinilai adalah aspek kebahasaan Ahli yang telah melakukan telaah pada produk juga memberikan saran untuk produk agar dapat lebih disempurnakan lagi sebelum diuji coba lapangan terbatas. Hasil telaah tim ahli menunjukkan bahwa sebagian besar butir pernyataan instrumen penilaian sikap sudah sesuai aspek sikap yang ingin dinilai, kriteria validitas instrumen yang diperoleh adalah rata-rata validitas tinggi dan layak diujicobakan karena memiliki skor $\geq 61 \%$. Produk yang telah diperbaiki sesuai saran ahli dan mendapatkan kesimpulan bahwa produk boleh diujicobakan dil lapangan terbatas. 
Tahap kelima yaitu Implementasi. Pada tahap implementasi, yaitu dengan memberikan produk kepada sasaran yaitu siswa. Produk diberikan kepada siswa kelas V SD Negeri 2 Kaligentong dengan 30 peserta didik untuk mengisi 30 butir pernyataan. Tahap terakhir yaitu evaluasi. Tahap evaluasi dilaksanakan berdasarkan umpan balik. Umpan balik sebagai dasar peneliti untuk memperbaiki produk sehingga dapat menghasilkan produk yang sempurna. Pada tahap evaluasi, yaitu adanya perbaikan dari ahli bahasa dengan data hasil telaah ahli bahasa menunjukkan bahwa pada nomor 3, 4, 5, 8 kata yang tidak jelas dan ambigu perlu diperbaiki. Oleh karena itu, tim ahli menyarankan untuk memperjelas kalimat dan memperhalus kata-kata yang digunakan. Pernyataan nomor 3 yang mulanya "Saya menyelesaikan tugas yang dibagikan saat tugas kelompok" diperbaiki menjadi "Saya setuju jika anggota kelompok harus menyelesaikan tugas yang sudah dibagikan kepada masing-masing anggota". Pernyataan nomor 4 yang mulanya "Saya mengerjakan tugas dengan apa adanya sesuai dengan tugas yang diberikan" diperbaiki menjadi "Saya setuju untuk menyelesaikan tugas yang menjadi tugas saya sesuai tugas yang telah dibagikan kepada anggota kelompok". Pernyataan nomor 5 yang mulanya "Saya mencatat apa adanya sesuai dengan materi yang dipelajari" diperbaiki menjadi "Saya setuju jika saya secara sadar akan mencatat materi yang saya pelajari agar dapat lebih paham". Pernyataan nomor 8 yang mulanya "Saya melaksanakan tugas piket sesuai tugas saya dihari itu" diperbaiki menjadi "Saya suka jika dapat melaksanakan piket sesuai jadwal".

Pada tahap pengujian produk, yang telah diperbaiki sesuai saran ahli dan mendapatkan kesimpulan bahwa produk boleh diujicobakan. Produk diuji di kelas V SD Negeri 2 Kaligentong dengan 30 peserta didik untuk mengisi 30 butir pernyataan. Produk diujicobakan tingkat validitas dan reliabilitasnya.. Data hasil pengolahan IBM SPSS 24 dapat diamati dalam tabel berikut ini :

Tabel 4. Rincian Hasil Validitas Instrumen Uji Coba Produk Lapangan

\begin{tabular}{|c|c|c|c|}
\hline \multirow[t]{2}{*}{ Rentang Indeks } & \multirow[t]{2}{*}{ Kategori } & \multicolumn{2}{|c|}{ Uji Coba Produk Lapangan } \\
\hline & & Fekuensi butir soal & $\%$ \\
\hline $0,81-1,00$ & Sangat Tinggi & 3 & 10 \\
\hline $0,61-0,80$ & Tinggi & 13 & 43.33 \\
\hline $0,41-0,60$ & Cukup & 13 & 43.33 \\
\hline $0,21-0,40$ & Rendah & 1 & 3.33 \\
\hline \multicolumn{2}{|c|}{ Jumlah } & 30 & 100 \\
\hline
\end{tabular}

Berdasarkan hasil uji validitas diatas, diketahui bahwa $r_{\text {tabel }}=0,361$, sehingga instrumen dinyatakan valid jika $r_{\text {hitung }} \geq 0,361$. Hasil pengolahan data diatas diperoleh bahwa $r_{\text {hitung }}$ (korelasi) terendah dari 30 butir pernyataan sebesar 0.385 , r ritung 0.385 berada diantara 0,21 - 0,40, skor tersebut valid dengan tingkat validitas rendah. Hasil uji coba produk mendapat $\mathrm{r}_{\text {hitung }}$ (korelasi) tertinggi sebesar 0.856 yang berada diantara 0,81 - 1,00 dengan tingkat validitas sangat tinggi. Hasil penelitian dan pengembangan instrumen penilaian sikap tanggung jawab siswa SD kelas $\mathrm{V}$, menunjukkan semua item instrumen dalam kategori valid.

Hasil uji reliabilitas dengan koefisien reliabilitas instrumen yang diolah menggunakan program IBM SPSS 24 for windows dengan cara klik Analyze, Scale, Reliability Analysis, centang pada Item, Scale, Scale if item deleted, continue dan klik ok. Muncul tabel Reliability Statistics, dan jika nilai pada Cronbach's-Alpha > 0,361 dinyatakan reliabel. Hasil uji reliabilitas instrumen penilaian sikap sosial pembelajaran tematik pada uji coba terbatas disajikan melalui tabel berikut ini.

Tabel 5. Hasil Uji Reliabilitas Instrumen Uji Coba Produk Lapangan Terbatas

\begin{tabular}{cc}
\hline Interpretasi Reliabilitas & Nilai Cronbach's Alpha \\
\hline$\alpha \geq 361$ & 0,944 \\
\hline
\end{tabular}

Berdasarkan tabel reliabilitas instrumen pada uji coba lapangan terbatas memiliki tingkat reliabilitas instrumen dengan $\alpha$ sebesar 0.944 dengan kriteria sangat reliabel untuk digunakan. Tingkat reliabilitas dengan $\alpha>0.8$ yaitu sebesar 0.944 mendapatkan kriteria sangat reliabel. Hasil penelitian dan pengembangan instrumen penilaian sikap tanggung jawab siswa kelas $\mathrm{V}$, menunjukkan keterandalan yang sangat reliabel dalam mengukur sikap siswa. 
Instrumen penilaian sikap tanggung jawab siswa kelas $\mathrm{V}$ semester 2, menunjukkan keterandalan yang sangat reliabel dalam mengukur sikap siswa. Reliabilitas produk instrumen penilaian sikap dilihat dari reliabilitas instrumen pada uji coba lapangan terbatas memiliki tingkat reliabilitas instrumen dengan $\alpha$ sebesar 0.944 dengan kriteria sangat reliabel untuk digunakan. Tingkat reliabilitas dengan $\alpha>0.8$ yaitu sebesar 0.944 mendapatkan kriteria sangat reliabel. Koefisien reliabilitas instrumen dapat dilihat menggunakan program IBM SPSS 24 for windows dengan cara klik Analyze, Scale, Reliability Analysis, centang pada Item, Scale, Scale if item deleted, continue dan klik ok. Muncul tabel Reliability Statistics, dan jika nilai pada Cronbach's-Alpha $>0,361$ dinyatakan reliabel. Berdasarkan hasil uji validasi oleh ahli evaluasi sikap dan ahli bahasa dapat disimpulkan bahwa instrumen penilaian sikap tanggung jawab memiliki kategori Tinggi (Valid) dan layak digunakan. Hal tersebut disebabkan oleh beberapa faktor yaitu sebagai berikut.

Pertama, instrumen penilaian sikap tanggung jawab siswa kelas $\mathrm{V}$ dapat mengukur sikap tanggung jawab siswa dalam pengukuran sikap secara objektif. Pengembangan dan perumusan instrumen dikembangkan dengan mengacu pada panduan penilaian sekolah dasar dan mengacu pada rambu-rambu penyusunan skala sikap model Likert untuk mengukur sikap siswa (Kuntoro \& Wardani, 2020; Mawardi, 2019). Hasil penelitian dan pengembangan instrumen penilaian sikap tanggung jawab siswa SD kelas V, menunjukkan semua item instrumen dalam kategori valid. Instrumen yang dinyatakan valid maka instrumen tersebut layak untuk digunakan dan termasuk penilaian yang autentik yakni melalui teknik penilaian ini dapat mengungkapkan, membuktikan atau menunjukkan secara tepat pada tujuan pembelajaran dan kemampuan (kompetensi) telah benar-benar dikuasai dan dicapai (Kuntoro \& Wardani, 2020; Wildan, 2017). Dikembangkan RPP yang memuat pembelajaran inovatif berdasarkan materi terpilih. Kemudian, dikembangkan kisi-kisi instrumen yang memuat objek sikap, indikator, dan ranah aspek sikap siswa. Selanjutnya dikembangkan instrumen penilaian sikap siswa yang menarik, praktis, tidak membingungkan siswa dalam mengisinya. Praktisnya juga bisa dikirimkan kepada siswa melalui Google Formulir jika dalam pembelajaran jarak jauh (PJJ). Setelah siswa mengerjakan guru kelas dapat merekap hasil siswa kemudian dapat langsung memperoleh skor total yang dibagi skor maksimal lalu dikalikan 100\% dapat langsung diperoleh hasil kategori nilai sikap siswa.

Kedua, instrumen penilaian sikap tanggung jawab siswa kelas $\mathrm{V}$ bersifat praktif sehingga mudah digunakan oleh guru. Instrumen sikap tanggung jawab dengan skala Likert dapat menilai sikap individu siswa dan praktis dalam pelaksanaannya. Pelaksanaan penilaian sikap sosial dengan cara angket menggunakan skala Likert ini dapat dengan rinci menilai sikap sosial dari individu siswa dan hasil penilaian yang diperoleh dapat diolah dengan mudah, serta dapat menilai sesuai kompetensinya. (Ningsih, 2018; Wicaksono, Muhardjito, \& Harsiati, 2016). Butir pernyataan instrumen yang valid telah disajikan telah kontekstual atau sesuai dengan aktivitas siswa dikehidupan sehari-hari, memuat cakupan materi, dan isi instrumen mewakili KD, serta definisi sikap sebagai objek ukur dinilai sangat sesuai dengan produk yang dikembangkan karena sudah memenuhi syarat kevalidan (Novitasari \& Wardani, 2020; Suryabrata, 2012; Wicaksono et al., 2016).

Hasil penelitian ini, sejalan dengan penelitian yang dilakukan oleh Kuntoro \& Wardani (2020) yang menghasilkan instrumen penilaian sikap "sangat reliable" dengan koefisien $\alpha$ 0,935; 0,911 dan 0,914, koefisien $\alpha$ berada diantara 0,810-1,000. Penelitian yang sama dilakukan oleh Prasanti (2017) hasil uji reliabilitas menunjukan hasil sebesar 0,643 maka instrumen memiliki reliabilitas yang tinggi. Penelitian yang sama dilakukan oleh Kuntoro \& Wardani (2020) hasil penelitian menunjukkan $r_{\text {hitung }}$ paling rendah $0,414 \geq 0,20$ maka instrumen dinyatakan valid. Sejalan dengan Kuntoro, penelitian yang sama dilakukan oleh Candra et al., (2018) hasil penelitian menunjukkan rata-rata $r_{\text {hitung }}>0,300$ terhadap 16, 19, dan 23 siswa adalah 30 (100\%) butir pernyataan valid. Sehingga instrumen sikap sosial tematik dapat dinyatakan sebagai instrumen hasil pengembangan berupa instrumen yang valid.

Implikasi penelitian ini yaitu instrument yang dikembangkan dapat digunakan oleh guru untuk mengukur sikap tanggung jawab siswa kelas $\mathrm{V}$. Instrumen penilaian sikap tanggung jawab kelas $\mathrm{V}$ semester 2 dikembangkan sesuai pembelajaran tematik yang relevan dengan perkembangan usia siswa sehingga dapat mengukur secara konstan dan dapat dijadikan panduan atau alat ukur di tahun ajaran berikutnya. Manfaat instrumen penilaian sikap yang reliabel adalah alat ukur yang dapat memberikan hasil yang konstan, instrumen ini mampu menunjukkan hasil yang konstan dalam mengukur kejadian yang sama pada waktu yang berbeda (Kuntoro \& Wardani, 2020; Wardani, N.S, 2012). 


\section{Simpulan}

Berdasarkan hasil uji validasi oleh ahli evaluasi sikap dan ahli bahasa, instrumen penilaian sikap tanggung jawab memiliki kategori Tinggi (Valid) dan layak digunakan. Berdasarkan uji validasi lapangan terbatas menunjukkan hasil dengan 30 butir pernyataan masuk dalam kategori valid. Hasil uji reliabilitas atau keterandalan produk dengan pengolahan data menunjukkan hasil bahwa produk instrumen penilaian sikap tanggung jawab memiliki kriteria sangat reliabel atau sangat andal.

\section{Daftar Pustaka}

Adjii, K. (2019). Instrumen penilaian kedisiplinan siswa sekolah menengah kejuruan. Assessment and Research on Education, 1(1). https://doi.org/http://dx.doi.org/10.33292/arisen.v1i1.19

Astuti, S. I., \& Darsinah, D. (2018). Penilaian Autentik Berbasis Kurikulum 2013 di SD Negeri Mangkubumen Kidul No. 16 Surakarta. Manajemen Pendidikan, 13(2), 165-174. https://doi.org/10.23917/jmp.v13i2.7484

Baidhowi. (2018). Instrumen Penilaian Sikap Sosial (Studi Penilaian Sikap Sosial pada mata pelajaran Fikih di Jurusan Tehnik dan Bisnis Sepeda Motor SMK Muhammadiyah 1 Patuk) Muhammad Rizal. Jurnal Edudeena, 2(1). https://doi.org/https://doi.org/10.30762/ed.v2i1.518

Candra, I., Sulistya, N., \& Prasetyo, T. (2018). Pengembangan Instrumen Sikap Sosial Tematik Siswa SD Kelas IV. Jurnal Ilmiah Sekolah Dasar, 2(4), 455. https://doi.org/10.23887/jisd.v2i4.16167

Darmansyah, D. (2014). Teknik Penilaian Sikap Spritual dan Sosial dalam Pendidikan Karakter di Sekolah Dasar 08 Surau Gadang Nanggalo. Al-Ta Lim Journal, 21(1), 10-17. https://doi.org/10.15548/jt.v21i1.67

Dessiane, S. T., \& Kristin, F. (2021). Pengembangan Instrumen Penilaian Sikap Sosialpembelajaran Tematik Kelas 4 SD. 6, 21-26. https://doi.org/https://dx.doi.org/10.26737/jpipsi.v6i1.2310

Kuntoro, B. T., \& Wardani, N. S. (2020). Pengembangan Instrumen Penilaian Sikap Sosial Pembelajaran Tematik Kelas III SD. Jurnal Ilmiah Wahana Pendidikan, 6(3), 295-307. https://doi.org/10.5281/zenodo.3737983

Kurniaman, O., \& Noviana, E. (2017). Penerapan Kurikulum 2013 Dalam Meningkatkan Keterampilan, Sikap, Dan Pengetahuan. Primary: Jurnal Pendidikan Guru Sekolah Dasar, 6(2), 389. https://doi.org/10.33578/jpfkip.v6i2.4520

Mawardi, M. (2014). Model Desain Pembelajaran Konsep Dasar PKn Berbasis Belajar Mandiri Menggunakan Moodle. Semarang: Widya Sari Press.

Mawardi, M. (2019). Rambu-rambu Penyusunan Skala Sikap Model Likert untuk Mengukur Sikap Siswa. Scholaria: Jurnal Pendidikan Dan Kebudayaan, 9(3), 292-304. https://doi.org/10.24246/j.js.2019.v9.i3.p292-304

Mulyadin. (2016). Implementasi Kebijakan Pembelajaran Tematik Terpadu Kurikulum 2013 Di SDN Kauman 1 Malang Dan Sd Muhammadiyah 1 Malang. Jurnal Pendidikan Edutama, 3(2), 31 - 48. https://doi.org/http://dx.doi.org/10.30734/jpe.v3i2.35

Ningsih, Y. (2018). Penilaian Sikap Sosial Pada Anak Berkebutuhan Khusus Di Slb Negeri 2 Yogyakarta. Jurnal Bimbingan Dan Konseling Islam, 08(02), 208-215. https://doi.org/http://dx.doi.org/10.29080\%2Fjbki.v8i2.85

Novitasari, L., \& Wardani, N. S. (2020). Pengembangan Instrumen Sikap Toleransi Dalam Pembelajaran Tematik Kelas 5 SD. Jurnal Penelitian Tindakan Kelas Dan Pengembangan Pembelajaran, 3(1). https://doi.org/http://dx.doi.org/10.31604/ptk.v3i1.41-52

Nugraha, R. (2017). Evaluasi Penerapan Standar Penilaian Kurikulum 2013 Pada Kelas 4 Sekolah Dasar di Kecamatan Jambu. Jurnal Sekolah https://doi.org/https://doi.org/10.24114/js.v2i1.9925 
Oviana, W. (2015). Kemampuan Mahasiswa Mengintegrasikan Sikap Spiritual dan Sosial dalam Pembelajaran Berbasis Kurikulum 2013 (Kajian teoritis). Pionir Jurnal Pendidikan, 4(2). Retrieved from https://jurnal.ar-raniry.ac.id/index.php/Pionir/article/view/183/164\%0A

Prasanti, R. S. (2017). Pengembangan Instrumen Penilaian Sikap Sosial Pada Pembelajaran Tematik Kelas IV SD. Universitas Lampung.

Purwanti, et al. (2019). Sosialisasi Penilaian Sikap Peserta Didik pada Kurikulum 2013 bagi Guru SD Gugus Melati Kec. Ngaliyan Kota Semarang. Jurnal Abdimas, 23(1), 12-16. Retrieved from https://journal.unnes.ac.id/nju/index.php/abdimas/article/view/15174

Putra, E. D., \& Amalia, R. (2020). Upaya Meningkatkan Kemampuan Berpikir Kritis Mahasiswa Melalui Pembelajaran Discovery Learning Berbasis Assessment Learning. Journal of Education and Learning Mathematics Research (JELMaR), 1(1), 57-64. https://doi.org/10.37303/jelmar.v1i1.17

Sanjiwana, P.P.C.M Pudjawan, K., \& Margunayasa, I. G. (2015). Analisis Sikap Sosial Siswa Kelas V pada Pembelajaran dengan Kurikulum 2013. Jurnal PGSD Universitas Pendidikan Ganesha Jurusan PGSD, 3(1), 11-18. https://doi.org/http://dx.doi.org/10.23887/jjpgsd.v3i1.5631

Sari, D. A. P. (2017). Pengembangan Instrumen Penilaian Sikap Sosial Siswa Pada Pembelajaran Tematik Kelas IV Sekolah Dasar. Universitas Lampung.

Sugiyono. (2015). Metode Penelitian dan Pengembangan Research \& Development. Bandung: Alfabeta.

Sukmadinata, N. S. (2013). Metode Penelitian dan Pengembangan. Bandung: Remaja Rosdakarya.

Suryabrata, S. (2012). Psikologi Pendidikan. Jakarta: Raja Grafindo Persada.

Tursinawati. (2017). Analisis Rubrik Penilaian Sikap Siswa Pada Subtema Macam-Macam Sumber Energi Di Kelas IV SD Negeri 53 Banda Aceh. Prosiding Seminar Nasional Biotik, 4(1), 449-455. Retrieved from https://jurnal.ar-raniry.ac.id/index.php/PBiotik/article/view/2164

Utami, Purnomo, \& Salam. (2019). Penanaman Sikap Sosial Melalui Pembelajaran Ips Pada Siswa Smp Islam Sudirman Ambarawa Kabupaten Semarang. Sosiolium: Jurnal Pembelajaran IPS, 1(1), 4052. https://doi.org/https://doi.org/10.15294/sosiolium.v1i1.30446

Wardani, N.S, D. (2012). Asesmen Pembelajaran SD. Salatiga: Widya Sari Press.

Wicaksono, T. P., Muhardjito, \& Harsiati, T. (2016). Pengembangan penilaian sikap dengan teknik observasi , self assessment, dan peer assessment pada pembelajaran tematik kelas V SDN Arjowinangun 02 Malang. Jurnal Pendidikan: Teori, Penelitian, Dan Pengembangan, 1(1), 45-51. https://doi.org/http://dx.doi.org/10.17977/jp.v1i2.5214

Widodo, G. S., Hariyono, \& Hanurawan, F. (2016). Persepsi guru tentang kenakalan siswa : Studi kasus di sekolah dasar "Raja Agung ." Jurnal Pendidikan Dan Pembelajaraan, 23(2), 142-153. Retrieved from http://journal.um.ac.id/index.php/pendidikan-danpembelajaran/article/view/10165/4852

Widoyoko, E. P. (2014). Penilaian Hasil Pembelajaran di Sekolah. Yogyakarta: Pustaka Pelajar.

Wildan, W. (2017). Pelaksanaan Penilaian Autentik Aspek Pengetahuan, Sikap Dan Keterampilan Di Sekolah Atau Madrasah. Jurnal Tatsqif, 15(2), 131-153. https://doi.org/10.20414/jtq.v15i2.3 